
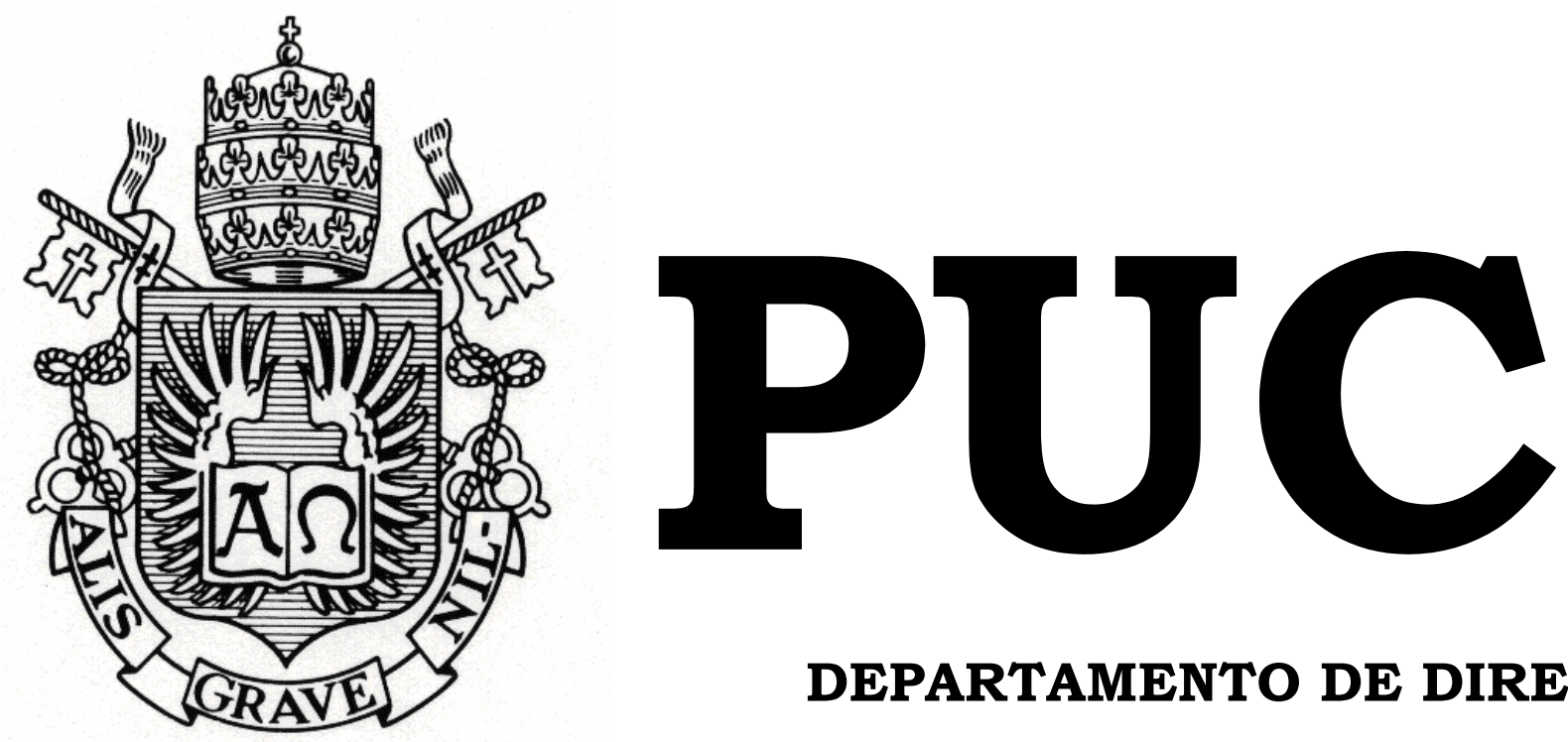

DEPARTAMENTO DE DIREITO

\title{
A legalidade da Guerra do Iraque perante o Direito Internacional
}

por

\section{TIAGO RIBEIRO DOS SANTOS}

ORIENTADOR: Florian Fabian Hoffmann

2005.1

PONTIFÍCIA UNIVERSIDADE CATÓLICA DO RIO DE JANEIRO

RUA MARQUÊS DE SÃO VICENTE, 225 - CEP 22453-900

RIO DE JANEIRO - BRASIL 


\section{A LEGALIDADE DA GUERRA DO IRAQUE PERANTE O DIREITO INTERNACIONAL}

por

\section{TIAGO RIBEIRO DOS SANTOS}

Monografia apresentada ao Departamento de Direito da Pontificia Universidade Católica do Rio de Janeiro (PUC-Rio) para a obtenção do Título de Bacharel em Direito.

Orientador: Prof. Florian Fabian Hoffmann 
Dedico o presente trabalho aos meus pais, pela companhia e alento no difícil caminho do amadurecimento e a Marcela, pelo apoio e compreensão.

Aos meus irmãos e amigos, pela companhia nas horas alegres e tristes.

Agradeço também ao meu orientador, pelo incentivo, por tudo que me ensinou e que me fez estudar, acompanhando com paciência a elaboração deste trabalho. 


\section{Resumo}

O presente trabalho monográfico tem o intuito de investigar a legalidade perante o direito internacional da Guerra do Iraque. Para isso, iremos verificar as hipóteses de legalidade de uma guerra perante o direito internacional vigente, e investigaremos se a própria Guerra do Iraque pode ter mudado o Direito Internacional. Verificamos que as exceções à proibição geral ao uso da força dada pelo art. 2(4) da Carta das Nações Unidas são encontradas nos arts. 51 e 53 da Carta, e que consistem na legítima defesa e na autorização do Conselho de Segurança. Apontaremos ainda a possibilidade do surgimento de um costume instantâneo internacional, que daria legitimidade à guerra, sendo tal espécie de costume aceita apenas por parte da doutrina internacional. Verificamos, entretanto, que a Guerra do Iraque não consegue preencher satisfatoriamente nenhum dos requisitos de legalidade, nem mesmo o controverso costume instantâneo, devendo ser considerada uma guerra ilegal.

Palavras-chave: 1) Iraque; 2) Legalidade de guerra internacional; 3) Legítima defesa preemptiva 


\section{Sumário}

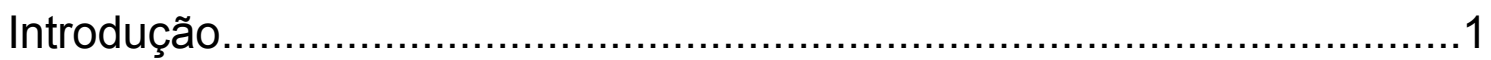

Primeiro capítulo - as hipóteses de legalidade de uma guerra

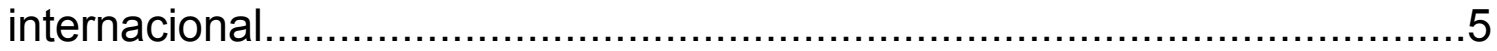

Segundo capítulo - a existência de legítima defesa no caso em tela.

Terceiro capítulo - a autorização do Conselho de Segurança no caso em tela.

Resoluções do Conselho de Segurança

Quarto capítulo - um costume instantâneo?

Conclusão 40

Bibliografia 43 


\section{Introdução}

Em 19 de março de 2003 as forças armadas americanas aliadas a britânicos e outras forças iniciaram a Segunda Guerra do Golfo, ou Guerra do Iraque. Essa é a guerra que produziu o maior número de baixas nas forças americanas desde a Guerra do Vietnã, e que já custou aos contribuintes norte-americanos mais de 200 bilhões de dólares ${ }^{1}$, tendo causado a morte de estimados $100.000^{2}$ civis iraquianos. As justificativas para a guerra têm constantemente mudado, mas determinação de realizá-la pode ser notada desde que o presidente George W. Bush proferiu discurso, em 29 de janeiro de 2002, em que inseriu o Iraque, junto com Irã e Coréia do Norte, no "Eixo do Mal".

A comoção internacional que precedeu a atitude norte-americana atingiu proporções globais. Havia na opinião pública mundial como um todo (com a exceção da maioria dos americanos e cidadãos de alguns outros países) um profundo sentimento de que a guerra era injusta e ilegal.. No dia 15 de fevereiro de 2003, mais de 1.5 milhão de europeus foi às ruas para opôr-se à guerra ${ }^{3}$, havendo protestos também no resto do mundo.

\footnotetext{
Os que conceberam a guerra, entretanto, sempre afirmaram a legalidade da intervenção, negando categoricamente que os ataques ferissem os princípios estabelecidos na Carta da ONU e no Direito Internacional. Tanto o Congresso Americano quanto o Attorney-General britânico fizeram declarações explícitas defendendo tal legalidade. A impressão que se tinha acompanhando as discussões é que a questão da legalidade da guerra havia tornado-se profundamente ideologizada, e mais confundia do que esclarecia a matéria.
}

O objetivo deste trabalho é investigar o Direito Internacional concernente a esta questão, procurando expor as visões mais aprofundadas e pertinentes sobre a matéria. Para tentar dar maior objetividade e facilitar conclusões o estudo será delimitado no tempo de maneira estrita. A legalidade que aí se investigará será a que ocorria, ou não, em relação às justificativas disponíveis no dia 19 de março de 2003, data do início da guerra. Ou seja, as justificativas para a legalidade da guerra que serão avaliadas são aquelas apresentadas no princípio do conflito, afastando-se justificativas quaisquer que venham a ser apresentadas no período após 19 de março

\footnotetext{
${ }^{1}$ Nationalpriorities.org, em http://www.nationalpriorities.org/Issues/Military/Iraq/highcost/costofwar.html ${ }^{2}$ Johns Hopkins Center for International Emergency, Disaster and Refugee Studies, apud The New York Times, 29/10/2004
} 
de 2003. Dessa maneira, a idéia de uma guerra feita em nome da democracia ou com quaisquer outros fins humanitários não será considerada neste estudo, por razões de definição de objeto.

Esta monografia está dividida em cinco capítulos. O primeiro trata das hipóteses de legalidade de uma guerra internacional no sistema onusiano; no segundo capítulo buscaremos saber se a primeira hipótese de legalidade, a legítima defesa, adequa-se ao caso em tela; no terceiro, se é adequada a segunda hipótese, autorização do Conselho de Segurança das Nações Unidas; no quarto capítulo, verificaremos se a Guerra do Iraque pode ter criado um costume instantâneo; no quinto e último capítulo faremos a conclusão do trabalho.

O primeiro capítulo é o em que iremos conhecer as hipóteses de legalidade de uma guerra internacional no DI vigente. Veremos que o direito à guerra é um direito que vem evoluindo há séculos no Direito Internacional, e que a Carta da ONU representa seu maior marco, tornando a legalidade de uma guerra exceção. Segundo as regras da Carta, hoje universalmente aceita pelos Estados, somente em legítima defesa ou por autorização do Conselho de Segurança podem os Estados incorrer em ataques armados. Veremos ainda neste capítulo as dificuldades que se apresentam ao formulador de política externa e ao jurista internacional em reconhecer em casos concretos a existência do direito à legítima defesa e também o problema do reconhecimento da autorização do Conselho de Segurança.

Cabe adiantar as grandes difículdades tanto quanto à configuração da legítima defesa, quanto ao reconhecimento de autorização. No primeiro caso, há intenso debate sobre a Carta ter ou não derrogado os institutos de legítima defesa que precediam a Carta. O esclarecimento desta questão é fundamental, pois os institutos de legítima defesa anteriores a São Francisco eram consistentemente mais amplos do que previsto explicitamente na Carta. Nesta matéria, um autor de Direito Internacional identifica duas correntes de juristas: os restricionistas, que acreditam ser a Carta a única fonte vigente a informar o direito a legitima defesa; e os contrarestricionistas, defensores da vigência do direito costumeiro anterior, mais amplo.

Dentre os institutos de legítima defesa vigentes no direito costumeiro pré-45 e não previstos na Carta da ONU destaca-se a legítima defesa preemptiva. Este

\footnotetext{
${ }^{3}$ The New York Times, 16/02/2003
} 
instituto permite - ou permitia - a um Estado em vias de ser atacado realizar a primeira investida, e é sobre essa forma de legítima defesa que se assentam alguns defensores da legalidade da Guerra do Iraque. Veremos que o grande parâmetro utilizado para se tratar deste instituto é o caso Caroline, de 1837, que estabeleceu os critérios configuradores da legítima defesa preventiva que se tornaram clássicos: necessidade, proporcionalidade e iminência.

Em relação à configuração da autorização, a dificuldade não é menor. A Carta não estabelece para o Conselho de Segurança uma forma específica, nem palavras essenciais, para legitimar forças armadas de um país a realizarem intervenções armadas. Como veremos, a História mostra que os membros do Conselho costumam ser vagos nesta matéria, tornando-a deveras mais nebulosa do que o desejável. Assim, as intervenções irão ocorrer quando algum Estado entender ter havido autorização do Conselho e enviar suas tropas a fim de realizar a intervenção.

No segundo capítulo, vamos aplicar as regras genéricas que se utiliza para verificar um estado de legítima defesa ao caso concreto da Guerra do Iraque. Veremos se a ação dos EUA corresponde a uma medida que atende simultaneamente aos critérios de necessidade, proporcionalidade e iminência. Se todos os critérios estiverem satisfeitos, e se a legítima defesa preemptiva for um instituto ainda vigente, isto bastará para que a guerra seja legal do ponto de vista do Direito Internacional. Se algum critério não for atendido, entretanto, não haverá legalidade do ponto de vista da legítima defesa, ainda que o ataque satisfaça aos outros dois critérios.

No terceiro capítulo, será empreendida semelhante tarefa: utilizaremos as regras genéricas para o reconhecimento de uma autorização (se tais regras houver) e buscaremos responder se no caso concreto a autorização estava presente. Faremos nesse capítulo um breve panorama da crise EUA-Iraque, apontando as resoluções do Conselho de Segurança cruciais para o entendimento da matéria.

No quarto capítulo, trataremos da controversa hipótese de que a guerra tenha criado um costume instantâneo. Veremos que os elementos tradicionais do costume 
são a opinio juris dos Estados e que haja prática geral. Conheceremos, entretanto, opiniões divergentes da tradicional, que dispensam o elemento da prática, exigindo tão-somente a opinio juris. Verificaremos, dessa maneira, se, admitido a validade da teoria do costume instantâneo, a Guerra do Iraque teria sido legal

$\mathrm{Na}$ conclusão iremos nos valer de todas as questões analisadas anteriormente e buscaremos dar nossa própria visão quanto à legalidade da Guerra do Iraque, realizando também uma síntese dos principais pontos de vista na matéria, que é controvertida e, é claro, não poderia ser esgotada aqui. 


\section{Primeiro Capítulo - as hipóteses de legalidade de uma guerra internacional}

Nem sempre a guerra foi proibida pelo Direito Internacional. Na verdade, como ensina Celso Mello ${ }^{4}$, o Direito Internacional surgiu como direito eminentemente de guerra, não contrário à ela. Autores como Santo Agostinho buscaram definir o que seria uma guerra justa, utilizando, no entanto um critério moral, de forma que a guerra continuava não constituindo ilícitop 5 .

A evolução do Direito Internacional fez que no início do século já se estivesse prestes a tornar a guerra um ilícito internacional. A Sociedade das Nações, apesar de seu cunho pacifista, não chegou a proibir a guerra no texto de seu pacto, mas determinou em seu artigo 12 que ela fosse evitada. Em 1928, diversos países de todo o mundo renunciaram à guerra no Pacto Briand-Kellog, que possuía eficácia somente inter partes mas contou com grande número de adesões e provocou grande otimismo. O pacto foi ineficaz, contudo, na prevenção daquela que acabou sendo a maior guerra da história. $\mathrm{O}$ direito internacional mudaria, entretanto, com o advento das Nações Unidas.

A CARTA DA ONU PROÍBE QUE ESTADOS FAÇAM GUERRAS ENTRE SI OU PRATIQUEM QUALQUER ESPÉCIE DE AGRESSÃO. É O QUE DETERMINA O ARTIGO 2。 §4 DA CARTA: "TOdOS MEMBROS DEVERÃo EVITAR EM SUAS RELAÇÕES INTERNACIONAIS A AMEAÇA OU USO DA FORÇA CONTRA A INTEGRIDADE TERRITORIAL OU INDEPENDÊNCIA POLÍTICA DE QUALQUER ESTADO, OU QUALQUER OUTRA AÇÃO INCOMPATÍVEL COM OS PROPÓSITOS DAS NAÇÕES Unidas." ReConhece, PORÉm, em SEU aRtigo 51, O diReito de legítima DEFESA INDIVIDUAL OU COLETIVA:

\footnotetext{
${ }^{4}$ MELLO, Celso Duvivier de Albuquerque. Curso de Direito Internacional Público. Rio de Janeiro: Renovar, 2001, pg. 1430.

${ }^{5}$ REZEK, José Francisco. Direito Internacional Público (curso elementar). São Paulo, Saraiva, 2002, pg. 120.
} 
"NADA NA PRESENTE CARTA PREJUDICARÁ O DIREITO INERENTE DE LEGÍTIMA DEFESA INDIVIDUAL OU COLETIVA, NO CASO DE OCORRER UM ATAQUE ARMADO CONTRA UM MEMBRO DAS NAÇÕES UNIDAS, ATÉ QUE O CONSELHO DE SEGURANÇA TENHA TOMADO AS MEDIDAS NECESSÁRIAS PARA A MANUTENÇÃO DA PAZ E DA SEGURANÇA INTERNACIONAIS. AS MEDIDAS TOMADAS PELOS MESMOS NO EXERCÍCIO DESSE DIREITO DE LEGÍTIMA DEFESA SERÃO COMUNICADAS IMEDIATAMENTE AO CONSELHO DE SEGURANÇA NÃO DEVERÃO, DE MODO ALGUM, ATINGIR AUTORIDADE E A RESPONSABILIDADE QUE A PRESENTE CARTA ATRIBUI AO CONSELHO PARA LEVAR A EFEITO, EM QUALQUER TEMPO, A AÇÃO QUE JULGAR NECESSÁRIA À MANUTENÇÃO OU AO RESTABELECIMENTO DA PAZ E DA SEGURANÇA INTERNACIONAIS".

ESSA É UMA DAS HIPÓTESES QUE ESTADOS SOBERANOS TÊM A FIM DE EXERCER LEGALMENTE A FORÇA NAS RELAÇÕES INTERNACIONAIS.

AfastadA a legítima defesa, A FORÇA SOMENTE SERÁ LEGAL SE determinada pelo Conselho de Segurança da ONU. É O que está PREVISTO NO ARTIGO 53 DA CARTA:

\begin{abstract}
"O Conselho de Segurança utilizarÁ, quando for o caso, tais ACORDOS DE ENTIDADES REGIONAIS PARA UMA AÇÃO COERCITIVA SOBRE A SUA PRÓPRIA AUTORIDADE. NENHUMA AÇÃO COERCITIVA SERÁ, NO ENTANTO, LEVADA A EFEITO DE CONFORMIDADE COM ACORDOS OU ENTIDADES REgIONAIS SEM AUTORIZAÇÃo dO CONSELHO DE SEGURANÇA COM EXCEÇÃo DAS MEDIDAS CONTRA O ESTADO INIMIGO, COMO ESTÁ DEFINIDO NO PARÁGRAFO $2^{\circ}$ DESTE ARTIGO, QUE FOREM DETERMINADAS EM CONSEQÜÊNCIA DO ARTIGO $107^{6}$ OU EM ACORDOS REGIONAIS DESTINADOS A IMPEDIR A RENOVAÇÃO DE UMA POLÍTICA AGRESSIVA POR PARTE DE QUALQUER DESSES ESTADOS, ATÉ O MOMENTO EM QUE A ORGANIZAÇÃO POSSA, A PEDIDO DOS GOVERNOS INTERESSADOS, SER DE INCUMBIDA DE IMPEDIR TODA NOVA AGRESSÃO POR PARTE DE TAL ESTADO."
\end{abstract}

NÃO SE ENCONTRA EM QUALQUER OUTRO ARTIGO DA CARTA DA ONU POSSIBILIDADE DE EXERCER A FORÇA LEGALMENTE NAS RELAÇÕES INTERNACIONAIS.

AMBAS HIPÓTESES - LEGÍTIMA DEFESA E AUTORIZAÇÃO DO CONSELHO DE SEgURANÇA - FORAM UTILIZADAS PARA JUSTIFICAR A GUERRA DO IRAQUE. A PRIMEIRA, INDIRETAMENTE, PELO PRESIDENTE DOS EUA NUM DISCURSO EM 
2002, em West Point ${ }^{7}$. A segunda fol utilizada diretamente pelo ATTORNEY-GENERAL BRITÂNICO, LORD GOLDSMITH'.

DIANTE DAS PROIBIÇÕES E PERMISSÕES GENERICAMENTE ESTABELECIDAS NA CARTA, SURGEM OS DOIS PRINCIPAIS FATORES DE CONTROVÉRSIA QUANTO À LEGALIDADE dO USO DA FORÇA. NO QUE TOCA À legítIMA DEFESA, hÁ divergêncla relativamente À derRogaÇão ou não, pela Carta, de INSTITUTOS DE LEGÍtIMA DEFESA PREVISTOS NO D.I. ANTERIOR A SÃo FRANCISCO - EM SEU DISCURSO, O PRESIDENTE BUSH FALOU EM "PREEMPÇÃO" ("PREEMPTION"), FORMA DE LEGÍTIMA DEFESA QUE NÃO ESTÁ PREVISTA EM TRATADO, O QUE TORNA RELEVANTE A INVESTIGAÇÃo. EM RELAÇÃo À AUTORIZAÇÃo do CONSELHO dE SEGURANÇA, A FALTA DE FORÇAS REGULARES DAS NAÇÕES UNIDAS TORNA PROBLEMÁTICO O RECONHECIMENTO DO MOMENTO EXATO EM QUE O CONSELHO EFETIVAMENTE AUTORIZA A INTERVENÇÃO.

\section{Legítima defesa preemptiva}

\section{Preemptiva ou preventiva?}

A doutrina brasileira, bem como parte da estrangeira, não costuma distinguir a guerra preemptiva da guerra preventiva. Acreditamos, contudo, que a classificação da doutrina estrangeira é bastante lógica e de grande utilidade neste estudo.

Embora haja bastante mudança de termos de autor para autor, como mostra Kaufman ${ }^{9}$, as idéias principais convergem. Desta maneira uma forma de realizar a distinção é classificar a primeira como a espécie de legítima defesa focada na intenção de um Estado de praticar uma agressão, e a segunda como a que mira em sua capacidade agressora. Assim, a legítima defesa preemptiva é invocada em relação a estados que estão prestes a efetivamente desferirem um ataque contra determinado estado, enquanto a legítima defesa preventiva é desferida contra estados que estão armando-se além do que é considerado seguro pelo estado que a invoca. A legítima defesa preventiva é considerada ilegal, de maneira razoavelmente consensual ${ }^{10}$.

Legítima defesa preemptiva

\footnotetext{
${ }^{6} \mathrm{O}$ artigo 107 da Carta das Nações Unidas determina que a Carta da ONU não invalidará qualquer ação dos aliados na $2^{\mathrm{a}}$ Guerra Mundial, que constituíam então as Nações Unidas, em relação aos Estados inimigos naquela guerra, ou seja, os componentes do Eixo.

${ }^{7}$ Apud O'CONNELL, Mary Ellen. “The Myth of Preemptive Self-defense”. The American Society of International Law Task Force on Terrorism. Agosto, 2002.

${ }^{8}$ CNN.com. Disponível em http://www.cnn.com/2003/WORLD/meast/03/17/sprj.irq.uk.legal/

${ }^{9}$ KAUFMAN, Whitley R. P. "What's Wrong with Pre-emptive War?" The Joint Services Conference On

Professional Ethics. 2005

${ }^{10}$ Ibibid..
} 
A definição de legítima defesa preemptiva consagrada no D.I costumeiro é a que se expôs no célebre caso Caroline, entre Grã-Bretanha e EUA ${ }^{11}$, em 1837. Naquela ocasião, um navio a vapor norte-americano - o Caroline - foi afundado pela marinha britânica por transportar mantimentos e pessoas para a então colônia Canadá a fim de ajudar rebeldes daquele país desejosos da independência. $\mathrm{O}$ governo norte americano protestou contra o ataque, tendo recebido retratação por parte do Reino Unido. A partir de então, dariam ensejo à legítima defesa preemptiva "cases in which the necessity of that self-defense is instant, overwhelming, and leaving no choice of means and no moment for deliberation". Segundo o direito costumeiro, portanto, ainda que não tenha havido ataque armado, surge o direito à legítima defesa quando um ataque reúne os atributos de 1) iminência 2) proporcionalidade, e 3) necessidade ${ }^{12}$. A admissão pelo Direito Internacional é matéria problemática, bem sintetizada por Shaw (790:1997):

\begin{abstract}
"The trouble, of course, with the concept of anticipatory self-defense is that it involves fine calculations of the various moves by the other party. A pre-emptive strike embarked upon too early might constitute an aggression. There is a difficult line to be drawn. The problem is that the nature of the international system is such as to leave such determinations to be made by the states themselves, and in the absence of an acceptable, institutional alternative, it is difficult to foresee a modification of this". ${ }^{13}$
\end{abstract}

Quais efeitos a Carta da ONU teve sobre esse instituto de D.I., entretanto, é matéria de disputa acadêmica, que passaremos a analisar.

A leitura inicial do artigo 51, que trata da legítima defesa parece ser bastante clara quanto às hipóteses em que o direito surgiria: nada impedirá o uso da força "no caso de ocorrer um ataque armado ('if an armed attack occurs',)". O uso da expressão "direito inerente" à legítima defesa, entretanto, torna a matéria controversa. Alegam alguns autores que a expressão significaria o reconhecimento das Nações Unidas do direito costumeiro à legítima defesa, ou seja, admitir-se-ia

\footnotetext{
${ }^{11}$ ACKERMAN, Davibid. "International Law and the Preemptive Use of Force Against Iraq" CRS Report for Congress. Congressional Research Service - The Library of Congress. Março, 2003.

${ }^{12}$ ibibid.

${ }^{13}$ SHAW, Malcolm Nathan. International Law. Cambridge University Press, 1997, pg 790.
} 
que, no que toca à legítima defesa estatal, estaria afastada a própria Carta, vigorando as práticas até então vigentes ${ }^{14}$.

Arend observa duas correntes, dentro do positivismo, que possuem visões opostas sobre a legalidade de ataques preemptivos. Uma, restricionista, entende que a Carta da ONU extinguiu o direito à legítima defesa preemptiva. Outra, "contrarestricionista”, considera que a Carta não proibiu a prática. Segundo o autor, para os restricionistas, a proibição geral ao uso da força contida no art. 2(4), e a expressão "no caso de ocorrer um ataque armado", claramente derrogam o direito costumeiro à legítima defesa. Em relação aos contra-restricionistas, o autor não identifica uma unidade de argumento, porém aponta que as alegações desses estudiosos costumam girar em torno da já citada expressão direito "inerente".

Seguindo a classificação de Arend, é restricionista a visão de O’Connel, encontrada no texto com o expressivo título "The Myth of Preemptive SelfDefense": "Reading the Charter as a whole, it is evident that the prohibition of force was intended by the charters to be very broad, admitting of only explicit exceptions. This conclusion is confirmed by the drafting history of the Charter"15. Para ilustrar seu ponto de vista, a autora cita a posição norte-americana na Convenção de São Francisco, que daria origem à Carta. Disse então o delegado norte-americano: "[T]he intention of the authors of the original text was to state in the broadest terms an absolute all-inclusive prohibition; the phrase 'or in any other manner' was designed to ensure that there would be no loopholes" ${ }^{\text {"16 }}$. É também restricionista a opinion juris de Caron:

"The design of the U.N. Charter errs toward prohibiting war. One either must have authorization of the Council, or there must be 'an armed attack' against which one individually or collectively acts in self-defense. That choice, to tend toward prohibiting the use of force,

\footnotetext{
${ }^{14}$ Afastaremos aqui a visão de O'Connel (op. cit.), que sustenta ser o costume hierarquicamente superior ao tratado, de modo que a Carta da $\mathrm{ONU}$, sendo um tratado, não poderia tornar ilegal uma norma costumeira (apud Rezek, 2002, pg 120).

${ }^{15} \mathrm{O}^{`}$ Connel, op. cit., pg 6.

${ }^{16}$ Apud O'Connel, op. cit., pg. 7.
} 
reflected the lessons learned from two world wars when the Charter was written in $1945^{\prime \prime 17}$.

Entre os denominados "contra-restricionistas", o próprio Arend identifica o juiz norte-americano da Corte Internacional de Justiça, Stephen Schwebel. Para ele, se a Carta pretendesse ser taxativa quanto ao uso da força, teria de haver a expressão "if, and only if, an armed attack occurs" no art. $51^{18}$. Entende o jurista que a falta da expressão demonstra a admissão, pela Carta, da existência de legítima defesa em outras hipóteses que não se enquadrem na categoria de resposta a um ataque armado.

O'Connell critica a teoria do direito inerente:

"A teoria do 'direito inerente' possui numerosas fraquezas, a começar por sua interpretação do direito costumeiro anterior à adoção da Carta. Ao tempo do caso Caroline, citado em favor da teoria, o uso da força era em princípio um instrumento legítimo de política nacional. A Carta da ONU foi adotada justamente com o propósito de criar uma proibição significativamente mais ampla do uso da força do que a proibição vigente por tratado e costume anterior a 1945. Ainda que o costume anterior autorizasse a legítima defesa preemptiva, a argüição de que aquele costume persiste, após 1945, para os membros da ONU, requer a prevalência da palavra "inerente" sobre os termos objetivos do Artigo 2(4) e sobre as palavras "ataque armado" contidas no artigo 51."

Acrescentaria-se às críticas de O'Connel à teoria do direito inerente a constatação que direito inerente não pode ser confundido com direito costumeiro. A idéia de direito inerente remete ao direito natural, a um direito que os estados possuiriam simplesmente por serem estados. Poderia-se considerar, de certa maneira, que o direito inerente à legítima defesa de um estado é análogo aos direitos humanos que possuem os indivíduos. O direito costumeiro, tal como o de legítima defesa preemptiva, no entanto, é perfeitamente mutável. O fundamento da obrigatoriedade do costume não é qualquer norma superior, mas o próprio

\footnotetext{
${ }^{17}$ CARON, Davibid. Palestra proferida em 1 de abril de 2003 no Zellerbach Hall na Universidade de Berkeley, EUA.

${ }^{18}$ Apud AREND, Anthony Clark. "International Law and the Preemptive Use of Military force". The

Washington Quarterly. Primavera, 2003.
} 
consentimento dos estados (REZEK, 2002 - pg125). Desta maneira, o significado da expressão direito inerente parece ser que as Nações Unidas reconhecem que o direito abstrato à legítima defesa estatal está acima da Carta, mas que a disciplina de tal direito encontra-se no texto.

A Corte Internacional de Justiça, por sua vez, e a despeito da opinião supra citada do juiz Schwebel, possui visão ainda mais restritiva do que alguns autores. Para a Corte, tanto o sistema ONU como o direito costumeiro exigem que haja um ataque armado para que surja o direito à legítima defesa:

"[F]or one State to use force against another ... is regarded lawful, by way of exception, only when the wrongful act provoking the response was na armed attack ... In the view of the Court, under international law in force today - wether customary international law or that of the United Nations system - States do not have a right of 'collective' armed response to acts which do not constitute an 'armed attack'."

Há, todavia, autores que rejeitam o extremo positivismo de que alguns juristas se valem ao analisar a questão. Para os denominados "realistas" do Direito Internacional, as circunstâncias da sociedade internacional devem ser analisadas na determinação da legalidade do uso da força, pois interpretações demasiado literais poderiam esvaziar o D.I., tornando-o uma doutrina sem efeito; ou, mais grave, pôr em risco a paz internacional. Isto porque os realistas identificam mudanças fundamentais na capacidade dos estados de defenderem a si mesmo, e também no risco que se apresenta para eles na sociedade pós-1945. O argumento central é de que as armas de destruição em massa aumentaram o poder do primeiro ataque de tal maneira que impor a um estado a passividade até um ataque efetivo seria exigir-lhe o suicídio. Significaria, nas palavras do CRS, dar aos estados agressores o "direito à primeira investida" ("the right to the first strike').

Argumenta-se que durante a feitura da Carta os estados tinham a intenção de criar forças regulares das Nações Unidas, que ficariam responsáveis pela segurança internacional; e é em razão disto que a letra da Carta é tão restritiva. Diante do fracasso na criação de uma "polícia internacional", os estados vêm tentando adaptar as regras da Carta de maneira que produzam maior segurança, e a legítima defesa 
preemptiva é justamente uma destas regras que se busca alargar. É o que expõe Cassesse:

\begin{abstract}
"One of the first attempts to widen the meshes of the network of rules created in 1945 was to argue that article 51 authorizes not only self-defense against an aggression in full swing, but also preventive self-defense, whenever an attack is expected. ... This necessity, it is pointed out, is all the more compelling in a nuclear age, an age of missiles and jet planes"19.
\end{abstract}

\title{
A prática internacional
}

Para Arend, somente a avaliação da prática internacional pós-1945 é capaz de determinar a legalidade, ou não, das guerras preemptivas. Para isso, elege como casos exemplares a Guerra dos Seis Dias, de 1967; a Crise dos Mísseis, em Cuba, 1962; e o bombardeio do reator nuclear iraquiano em 1981 por Israel. Após analisar as declarações de diferentes chefes de Estado em relação aos eventos, crê não ser possível concluir que exista um consenso pela proibição de ataques preemptivos. O’Connel, entretanto, pronuncia-se sobre os eventos de 1967 e 1981, e declara ambos ilegais. Lembra a autora, ainda, que o bombardeio realizado por Israel em 1981 foi unanimemente condenado pelo Conselho de Segurança. Para reforçar sua argumentação, ela se vale da análise da prática reiterada dos estados, pois estes podem defender em um momento a existência de um direito que anteriormente negavam. De fato, como mostra a autora, os EUA lutaram para que a definição de legítima defesa fosse a mais restrita possível desde a elaboração da Carta. A própria expressão "no caso de ocorrer um ataque armado" foi inserida por insistência do delegado americano, e nunca os EUA defenderam a extensão do direito à legítima defesa preemptiva a toda a comunidade internacional.

A Corte Internacional de Justiça, por sua vez, não entende ser necessário que uma prática seja rigorosamente observada para que seja considerada obrigatória:

"The Court does not consider that, for a rule to be established as customary, the corresponding practice must be in absolutely rigorous conformity with the rule. In

\footnotetext{
${ }^{19}$ CASSESSE, Antonio. Violence and Law in the Modern Age. Oxford, Polity Press, 1986, pg. 35.
} 
order to deduce the existence of customary rules, the Court deems it sufficient that the conduct of States should, in general, be consistent with such rules, and that instances of State conduct inconsistent with a given rule should generally be treated as breaches of that rule, not as indications of the recognition of a new rule. If a State acts in a way prima facie incompatible with a recognized rule, but defends its conduct by appealing to exceptions or justifications contained within the rule itself, then whether or not the State's conduct is in fact justifiable on that basis, the significance of that attitude is to confirm rather than to weaken the rule" 20 .

Como observou Arend, não há consenso atualmente sobre a legalidade de um ataque preemptivo. Tanto a negação da legitimidade como sua afirmação parecem trazer insegurança aos Estados, que, se por um lado têm ojeriza à possibilidade de estarem à mercê do julgamento que outro Estado faz de sua atitude, tampouco se sentem confortáveis com a idéia de serem obrigados a esperar que um ataque armado lhes seja desferido para iniciar a defesa de sua soberania. Os incidentes de 11 de setembro, neste contexto, parecem pouco ter contribuído para a solução do impasse. Entretanto, aumentaram a incidência de políticas preemptivas nas relações internacionais.

\section{Autorização do Conselho de Segurança}

Como não há forças regulares da ONU que possam aplicar as medidas coercitivas decididas nas resoluções do Conselho de Segurança, as medidas somente podem tornar-se efetivas através da delegação do poder de uso legítimo da coerção às forças armadas dos estados-membros. A delegação do direito ao recurso à força, entretanto é atacada por vários estados, sobretudo pelos países não-alinhados ${ }^{21}$, com o argumento de que esta forma de solução dá às grandes potências um indevido poder discricionário a respeito de determinar o uso ou não da força, de que maneira usá-la, e quando usá-la. Ainda que as críticas sejam válidas, não se vislumbra

\footnotetext{
${ }^{20}$ Apud O’Connel, op. cit., pg. 16.

${ }^{21}$ LOBEL, James \& RATNER, Michael. "Bypassing the Security Council” American Journal of International Law. Janeiro, 1999.
} 
hipótese de, no curto (ou médio) prazo, mudar-se essa situação, de maneira que as autorizações devem continuar ocorrendo no cenário internacional.

Some-se à insegurança que tal poder discricionário das grandes potências traz às relações internacionais, o fato de nunca o Conselho de Segurança ter autorizado o emprego de força de maneira absolutamente explícita. Em detrimento de expressões como "Usando de força, se necessário", o Conselho no máximo autoriza a utilização de "todos os meios necessários" para fazer cumprir suas determinações ${ }^{22}$.

Lobel e Ratner identificam os seguintes problemas no sistema de autorizações: primeiro, o uso de forças por estados-membros que avaliam possuir autorizações implícitas nas resoluções do Conselho, não tendo aquela sido a intenção da resolução. Os autores identificam como um exemplo desta hipótese a ajuda humanitária que norte-americanos, franceses e britânicos concederam aos curdos em 1991, utilizando-se da Resolução 688, que não fez menção a força militar. O segundo problema que os autores apontam é o de estados que de fato possuem autorização para o uso da força interpretarem seus mandatos de maneira mais larga do que teria sido a vontade do Conselho. Como exemplo, citam a polêmica resolução 678, que deu início à Guerra do Golfo, e que, para os autores, limita o mandato à retirada das tropas iraquianas do Kuwait, mas que vêm desde então tendo interpretação mais ampla - como no caso da Guerra do Iraque. Identificam, por fim, problemas em relação à duração no tempo das resoluções. Quando não há um limite temporal estabelecido, é mais difícil determinar o fim de um mandato. Para os autores, "A key question is whether a permanent cease-fire or other definitive end to hostilities terminates Security Council authorizations to use force."

Poderíamos resumir as questões concernentes à autorização do Conselho às seguintes: 

$\mathrm{Ou}$, inversamente, autorizações implícitas são bastantes? Mais especificamente, um reconhecimento, pelo Conselho, de uma ameaça à paz é suficiente? O é o alerta para "graves conseqüências"? Ou somente a expressão "todos os meios necessários"?

2) Qual é a extensão de uma autorização? O que é restaurar a "paz e a segurança na Área", tal como determinado na resolução 678 ? A bem da verdade, o que é a "área"?

3) Quando termina uma autorização? Quando um cessar-fogo permanente é assinado? Quando da assinatura de um tratado de paz? $\mathrm{Ou}$ indefinidamente, sendo somente suspensa durante o tempo em que durar o cessar-fogo, podendo ser invocada sempre que um mandatário entender ter havido uma quebra material do acordo de cessar-fogo?

Essas são as questões sobre as quais buscaremos trazer alguma luz.

\section{O surgimento da autorização}

Parece natural que surgisse a autorização do emprego de força quando o Conselho de Segurança expressamente assim o determinasse, pois, sendo esta a vontade real do Conselho, nada o impediria de manifestá-la. A natureza das relações internacionais, entretanto, torna profundamente difícil que estados, sobretudo as grandes potências, manifestem-se a favor do uso da força contra um antigo aliado, ou mesmo contra um estado com que somente mantém relações. Argumenta-se, entretanto, que em diversas situações em que potências estavam dispostas a valer-se de seu poder de veto no Conselho, o emprego da força era no mínimo bastante

\footnotetext{
${ }^{22}$ Lobel e Ratner (op. cit.) contam que, quando da elaboração da resolução 678, que autorizou a retirada das forças iraquianas do Kuwait, a União Soviética negou a proposta americana de incluir a palavra "força",
} 
tolerável para os que se valem do veto, ou ainda, desejável. Como a urgência está sempre presente em situações de necessidade de intervenção armada, é motivo de aflição para muitos que meras questões diplomáticas possam estar impedindo o atingir do objetivo precípuo da ONU, qual seja, trazer paz e segurança nas relações internacionais.

Provavelmente o caso mais emblemático desta questão - a impossibilidade de conseguir-se autorização do Conselho, quando a intervenção era necessária, e alegadamente tolerável - é o de Kosovo, em 1998.

Como conta Bruno Simma ${ }^{23}$ o caso de Kosovo foi uma gravíssima crise humanitária que aconteceu no final de 1997 e início de 1998 e mobilizou a sociedade internacional. A violência indiscriminada do Exército Iugoslavo e das forças de segurança da Sérvia causou a morte de milhares de civis e o fluxo de outros tantos refugiados para a Europa, no período. Houve grande comoção internacional e tentativas de negociação, que foram frustradas. Em junho, quando do pedido do Secretário-Geral da ONU por uma resolução do Conselho, já estava claro que a Rússia não aceitaria tal votação.

Simma classificou este de um "hard case ${ }^{24}$, um caso em que o direito não pode fornecer uma resposta inequívoca, em que há conflito de normas. A proteção aos direitos humanos é um princípio fundamental da ONU, bem como o princípio de não-intervenção por um estado nos assuntos domésticos de outro estado previsto no art. 2(7) da Carta. Uma solução buscada para aquele caso especial foi a de considerar, primeiro, tal intervenção uma exceção, que não deveria abrir precedentes $^{25}$; segundo, aproximar ao máximo a ação da OTAN da legalidade. Assim, a OTAN sempre justificou sua ação em princípios da Carta da ONU e em resoluções do Conselho de Segurança, que consideravam a crise de Kosovo uma 'ameaça à paz'. Quando o Conselho editou a resolução 1203, que demonstrava um

\footnotetext{
apresentando a versão final a expressão "todos os meios necessários".

${ }^{23}$ SIMMA, Bruno. "NATO, the UN and the Use of Force: Legal Aspects" European Journal of International Law. 10, 1999.

${ }^{24}$ Ibid.

${ }^{25}$ Ibid.
} 
"remarkable degree of satisfaction" 26 com a ação da OTAN, alguns entenderam que se tratava de uma autorização implícita. Segundo o Kosovo Report "Even more indicative of a quasi-ratification of the NATO action was the willingess of the UNSC in Resolution 1244 to accept a central role for restoring normalcy to Kosovo on the basis of the NATO negotiating position at Rambouillet and elsewhere. ${ }^{27,}$ Simma, entretanto, não acredita ser possível falar em autorização implícita, pois a Rússia teria deixado claro que não concordaria com a intervenção e nunca teria deixado claro ter mudado sua posição. Em suas palavras: “... Russia had made it clear in the fall of 1998 that it was not ready to follow up on Resolutions 1160 and 1199 by agreeing to the ultimate step of unleashing armed force against the FRY. This position appears not to have changed since then."

Outros casos em que a autorização implícita foi aventada, segundo Lobel e Ratner seriam: 1) a independência de Goa, pela Índia, em 1961; 2) a crise dos mísseis, de 1962; 3) o ataque israelense ao reator nuclear iraquiano em 1981; 4) a intervenção de membros do ECOWAS em 1990 para estancar a guerra civil na Libéria; 5) a mencionada intervenção norte-americana, francesa e britânica em defesa dos curdos em 1991; e 6) a própria intervenção no Iraque.

Os seis casos, mais o de Kosovo, não seguem um padrão que possa apontar para uma consolidação dos requisitos de uma autorização implícita, a menos que se adote o critério do Professor D'Amato ${ }^{28}$ e considerar-se que toda ação armada que não corresponder a uma resposta, também armada, pelo Conselho de Segurança, adquire o status de legal por autorização implícita. A nosso ver, essa visão deve ser rejeitada, pois parece negar a própria existência do Direito Internacional, que deve ser geral e igual para todos estados soberanos. Se em razão das diferenças de poder entre os estados não é possível aplicar-se as sanções de maneira igual, não podemos tornar legal todo ato que não é sancionado. Na falta de um padrão objetivo, adotaremos neste trabalho critérios de razoabilidade a fim de verificar o surgimento de autorizações, pois certamente a natureza da matéria não permite que o direito 
simplesmente deixe de se pronunciar se houve ou não autorização em uma determinada situação.

\section{A extensão de uma autorização}

Novamente, o sistema de autorizações do CS traz dilemas para a sociedade internacional. Isto porque, se à primeira vista parece claro que as autorizações devem ser o mais restritas possível, tais restrições podem trazer diversos problemas para o mandatário que emprega suas forças. As guerras são acontecimentos extremamente dinâmicos, e a limitação excessiva da parte que luta pelo Direito Internacional, alega-se, pode ser profundamente nociva aos objetivos de obtenção da paz e da segurança internacionais.

Um caso que mostra o problema de limitarem-se em demasia as ações das tropas mandatárias do C.S. é apontado por Lobel e Ratner. Durante a primeira intervenção realizada em nome do CS na história, a Guerra da Coréia ${ }^{29}$, houve dúvidas quanto à permissão pela Resolução 83 de se ultrapassar o paralelo de $38^{\circ}$ com as tropas americanas. Aquela resolução autorizava "members of the United Nations to furnish such assistance to the Republic of Korea as may be necessary to repel the armed attack and to restore international peace and security in the area." $\mathrm{O}$ governo indiano e outros governos declararam acreditar ser necessária outra resolução. O governo americano, por outro lado, entendia que outro documento era dispensável. $\mathrm{O}$ argumento estadunidense era de que não seria possível, naquele momento, afirmar que a paz estava restabelecida, tendo em vista não haver então ao menos um cessar-fogo; havendo ainda, por parte dos norte-coreanos, sugestão de novas investidas sobre o sul. A despeito das considerações do governo norteamericano à época, que eram relevantes, os autores apontam o caso justamente como um reforço à interpretação restritiva quanto à extensão dos mandatos

\footnotetext{
${ }^{28}$ apud Lobel e Ratner, op. cit.

${ }^{29}$ Lobel e Ratner, op. cit.
} 
conferidos pelo CS, pois na ocasião o cruzamento do paralelo $38^{\circ}$ foi de fato aprovado pela Assembléia Geral.

\title{
A duração de uma autorização
}

Alguns autores acreditam que a assinatura de um cessar-fogo deveria extinguir uma autorização de uso da força do Conselho de Segurança. Se a regra é que o uso da força é proibido, e a autorização é exceção, esta deveria ser interpretada restritivamente.

Stevens, Wall e Dinlenc, entretanto, criticam esse ponto de vista :

\begin{abstract}
"The fundamental error of the position is this: it confuses suspension of hostilities with the termination of hostilities. As Professor Dinstein has emphasized, the legal status of a conflict remains unchanged after a cease-fire agreement has been reached: 'a suspension of hostilities connotes that the state of war goes on, but temporarily there is no warfare' There cannot be a 'reversion' back to Article 2(4) until the circumstances giving rise to lawful use of force are addressed and peace and security thereby restored, matters typically made the subject of a final peace agreement ${ }^{30}$,
\end{abstract}

Seguindo essa linha, portanto, somente extinguir-se-ia o mandato com a assinatura de um tratado de paz, e não um mero cessar-fogo; ou por nova resolução da ONU. Entretanto, entre um cessar-fogo estratégico e um tratado de paz há o cessar-fogo permanente, que dá fim às hostilidades, mas não às relações conflituosas entre os estados. Admitindo-se mesmo cessar-fogos permanentes não extinguem a autorização do Conselho, corolários perigosos para a realização dos objetivos da ONU de paz e segurança se apresentam. Como a assinatura de um cessar-fogo e o fim das hostilidades não significam o fim das relações conflituosas entre dois países, que podem estender-se por muitos anos ainda, a admissão de que um estado-membro pode investir sobre outro, com quem possui um acordo de cessar-fogo, sempre que o primeiro entender que houve uma "quebra material" do acordo, é como conceder aos estados mandatários uma "arma carregada", a ser 
utilizada sempre que conveniente. Ademais, se o acordo de cessar-fogo é realizado entre o país que sofre a intervenção e o Conselho de Segurança, e não entre o estado sob intervenção e os interventores, somente ao Conselho de Segurança caberia analisar se uma "quebra material" do acordo deve ser respondida com a força.

Neste ponto, deve ficar claro que as "quebras materiais" do acordo que necessitariam de autorização do CS para gerar direito ao uso da força não são agressões armadas. Naturalmente, se o estado sob intervenção comete uma agressão, o interventor não depende de autorização do CS para utilizar a força, pois o art. 51 da Carta da ONU o acolhe.

Lobel e Ratner utilizam o caso da Guerra Árabe-Israelense, de 1948, como lição sobre a duração dos mandatos. $\mathrm{Na}$ ocasião, um cessar-fogo foi imposto aos beligerantes, contendo as seguintes disposições:

"(1) No party may unilaterally put an end to the truce. (2) No party may take the law into its own hands and decree that it is relieved of its obligations under the resolution of the Security Council because in its opinion the other party has violated the truce ${ }^{31} . "$

Apesar do acordado, ambas as partes fizeram justamente o que era proibido pelo cessar-fogo e atacaram-se, alegando o descumprimento do cessar-fogo pela outra parte.

Deve ser apontado também que o caso é fundamentalmente diferente do que estamos tratando, pois, nos conflitos de 1948, nenhum estado atuava na condição de mandatário do CS.

Os autores supra citados mencionam ainda o caso da Coréia em defesa da tese de que cessar-fogos permanentes devem extinguir a autorização, pois do contrário uma possível avaliação norte-americana de que a Coréia do Norte quebrou materialmente alguma cláusula do armistício de 1953 faria reviver uma autorização concedida há mais de 50 anos, o que é classificado como absurdo.

\footnotetext{
${ }^{30}$ STEVENS, Paul Schott; WALL, Andru E. \& DINLENC, Ata. "The Just Demands of Peace and Security: International Law and the case against Iraq". The Federalist Society. Outubro, 2002.

${ }^{31}$ Sydney Bailey, apud Lobel e Ratner, op. cit.
} 
Decorre das idéias dos autores que, ainda que as forças armadas de um país mandatário devam possuir certa liberdade de agir, as ações tomadas devem estar em sintonia com o Conselho de Segurança, pois do contrário poderiam representar uma caixa de Pandora.

A admissão da duração indefinida de uma autorização após a assinatura de um cessar-fogo definitivo possui outro efeito grave apontado pelos autores, que é o do "veto reverso". Se há uma autorização que foi dada a um estado-membro em uma determinada época, e se se pretende extinguir a autorização por meio de resolução do Conselho de Segurança, a nova resolução, que busca a normalidade das relações, ou seja, a proibição do uso da força, a proibição pode ser frustrada com o veto de apenas uma das cinco potências. Nas palavras de Lobel e Ratner, ocorreria então uma inversão dos valores fundadores da ONU. A guerra, prevista para ser exceção, tornaria-se regra, nada podendo fazer os outros membros do Conselho para impedi-la. Como historicamente foram as cinco potências com poder de veto quem exerceu os mandatos do Conselho, teríamos uma situação em que a intervenção, realizada em nome do Conselho, duraria até que o estado mandatário assinasse um tratado de paz, ficando o Conselho refém de suas próprias resoluções.

Um possível efeito indesejado pela comunidade internacional de se admitir o "veto reverso" é que os membros do Conselho seguramente sentiriam-se menos à vontade para autorizar intervenções, temendo que sua autorização seja interpretada de maneira indesejada no futuro, quando as circunstâncias forem outras. Assim, se o Conselho já é criticado hoje por agir de maneira muito lenta, a admissão da legalidade do "veto reverso" poderia torná-lo verdadeiramente inoperante. 


\section{Segundo capítulo - a existência de direito à legítima defesa no caso em tela}

Embora os Estados Unidos tenham alegado coadunação de Saddam Hussein com a Al-Qaeda de Osama Bin Laden nos ataques de 11 de setembro, tal cooperação nunca foi provada, tendo a tese já sido abandonada pelo governo norteamericano. Em razão disso, a única hipótese de legítima defesa que poderia existir neste caso é a legítima defesa preemptiva, como mencionado por Bush em West Point.

Com a ressalva dos autores que entendem estar o instituto extinto, nós passaremos a investigar a existência de legítima defesa preemptiva a partir dos requisitos clássicos elaborados no caso Caroline, ou seja, buscar a existência de necessidade, proporcionalidade e iminência. Deve-se ressaltar que a intenção aqui não é invadir o campo da política e da tática militar, mas reservar-se ao campo jurídico, que define os requisitos mínimos de necessidade, proporcionalidade e iminência. Vale citar a lição de Caron, dada em uma palestra sobre a mesma guerra: "[L] egality should not be confused with the wisdom of a choice, with the legitimacy of that choice, or with morality. Just because one has the right possibly to do something does not mean that one should do so ${ }^{32}$." Não se trata de buscar substituir o julgamento de presidentes e generais nas decisões de quando fazer a guerra, e de que maneira fazê-la. O que o direito deve fazer é determinar quando ela $n \tilde{a} o$ pode ocorrer.

\section{Necessidade}

O que torna, para um Estado, necessário fazer a guerra? Se a Carta da ONU proíbe, de maneira geral, o recurso à força, somente permitindo-a a um estado em legítima defesa, a necessidade de recorrer à força deve impreterivelmente envolver

\footnotetext{
${ }^{32}$ Caron, op. cit.
} 
uma situação em que somente um ataque armado - pois se outros meios são possíveis, estes devem ser preferidos - pode prevenir uma violação de um direito que dê ensejo à legítima defesa. É claro que um estado jamais poderia alegar necessidade de utilizar a força para impedir que uma violação do direito internacional que não criaria o direito à legítima defesa chegue a acontecer. Contudo, não é pacífico quais são especificamente os direitos que podem ser protegidos pela legítima defesa. Creig $^{33}$ ensina que a doutrina vislumbra até cinco espécies de direitos que poderiam dar ensejo à legítima defesa: a integridade territorial, a independência política, a liberdade de navegação, a proteção de nacionais no estrangeiro e a proteção do bem-estar econômico de um estado. O autor não identifica quaisquer dificuldades em relação às duas primeiras espécies, e observa na decisão da CIJ do caso Corfu Channel uma autorização para a terceira. Em relação à proteção de nacionais no estrangeiro e à proteção do bem-estar econômico de um Estado, Creig aponta para controvérsias existentes na doutrina, não deixando de notar que na proteção de nacionais deve existir a proporcionalidade, e considerando "pouco provável" que a proteção de interesses financeiros possa permitir em algum momento o uso da força.

Seguindo Creig e descartando a proteção ao bem-estar econômico (que tampouco nos seria útil), e descartando também a liberdade de navegação e a proteção de nacionais americanos, qual, ou quais, das espécies justificaria o uso da força contra o Iraque? Verifiquemos:

1) Integridade territorial

Tendo-se abandonado a tese de co-conspiração de Saddam com a Al-Qaeda nos ataques de 11 de setembro, é impossível afirmar-se que a integridade territorial dos EUA estava sendo violada ou ameaçada quando começou a guerra. Não consta que tenha havido qualquer ameaça iraquiana diretamente ao povo norte-americano, tampouco tropas iraquianas chegaram mesmo próximas do território americano.

\footnotetext{
${ }^{33}$ CREIG, D.W. International Law. Londres, Butterworths, 1970.
} 
Ainda que a mera posse pelo Iraque de armas de destruição em massa, então alegada pelos EUA, constituíssem em uma ameaça à integridade territorial estadunidense, o que é altamente controverso e que nos furtaremos de discutir aqui, é certo que os elementos que o governo norte-americano possuía para acreditar no armamento iraquiano não poderiam ser suficientemente seguros para justificar uma guerra, e a prova cabal disto é que até o momento em que se escreve estas linhas, mais de ano e meio após o início da guerra, não se encontraram tais armas.

2) Independência política

Creig ensina que, embora as violações da integridade territorial de um Estado possam sempre significar uma ameaça à sua independência política, não é preciso que haja violação de território para que a independência política de um país esteja ameaçada:

"In many instances an attack against the former will involve an attack against the latter, but there may be situations in which by encouraging or promoting political agitation one state may endanger the political independence of another without necessarily infringing its territorial integrity ${ }^{34}$."

Assim, se o regime baathista vinha promovendo ou encorajando agitações políticas nos EUA, e se essas agitações punham em perigo a independência política norte-americana, surgiria o direito à legítima defesa.

Ora, é sabido que o governo iraquiano era hostil aos EUA, e provavelmente se regozijaria de agitações capazes de pôr em perigo a independência dos EUA. Entretanto, tais agitações jamais ocorreram em território americano; logo, não podemos falar de ameaça iraquiana à independência política americana.

\section{Proporcionalidade}

\footnotetext{
${ }^{34}$ Ibibid..
} 
Já vimos acima que aos Estados Unidos faltou o requisito de necessidade do ataque. Portanto, a avaliação de proporcionalidade encontra-se prejudicada. Entretanto, podemos, por ficção, avaliar a proporcionalidade do ataque americano se a ameaça de armas de destruição em massa existisse.

Nesse caso, o que seria um ataque proporcional? Se os Estados Unidos possuíam as provas das localizações dos arsenais iraquianos - o que eles alegavam possuir - é legítimo supor que um ataque proporcional seria aquele que se limitasse a destruir tal arsenal. Se considerarmos o ataque israelense ao mesmo Iraque em 1981 um ataque necessário - o que muitos não fazem, a bem da verdade-, ele certamente terá sido um ataque proporcional. Os bombardeios israelenses atingiram o reator nuclear iraquiano, minando sua capacidade nuclear, e limitaram-se a isso.

A Guerra do Iraque, entretanto, foi desde o princípio planejada para ser uma verdadeira invasão, destinada a subverter o regime iraquiano. Recente estudo da Johns Hopkins University aponta que teriam morrido, em razão da guerra, por volta de 100.000 civis iraquianos ${ }^{35}$, o que mostra que certamente não houve proporcionalidade.

\section{Iminência}

\footnotetext{
O direito costumeiro internacional, como vimos, não exige apenas a proporcionalidade e a necessidade, mas também a iminência de um ataque para que o direito à defesa antecipada possa surgir. No caso da Guerra do Iraque, este requisito estava claramente ausente, ainda que os outros dois existissem.
}

O discurso em West Point do presidente Bush se deu em 1 de junho de 2002. A Guerra do Iraque, entretanto, teve início em 11 de março de 2003. Nesse período de quase um ano os EUA levaram a questão à ONU diversas vezes, defendendo a Guerra. $\mathrm{O}$ ataque americano foi planejado minuciosamente por seus militares, e a data de início foi escolhida segundo a conveniência do governo norte-americano. Logo, nem mesmo os americanos acreditavam que havia qualquer iminência de

\footnotetext{
${ }^{35}$ BBCNews. Disponível em http://news.bbc.co.uk/2/hi/middle_east/3962969.stm
} 
ataque, pois deram-se ao direito de esperar o melhor momento para a invasão. $\mathrm{Na}$ verdade, toda argumentação de legítima defesa preemptiva feita anteriormente ao ataque irá sofrer da falta do requisito da iminência. É claro que se o Estado tem tempo para defender a legitimidade da sua ação, não está prestes a sofrer um ataque.

Como os EUA não conseguiram, no caso em tela, preencher os requisitos de legalidade de uma guerra preemptiva, nós devemos investigar a segunda hipótese de legalidade do uso da força, segundo a Carta da ONU. 


\section{Terceiro Capítulo - a existência de autorização do Conselho de Segurança no caso em tela}

Com a ressalva dos autores que entendem ser absolutamente necessária uma autorização explícita e inequívoca do Conselho de Segurança para que se possa realizar legalmente uma intervenção que não constitua legítima defesa, nós vamos a partir de agora buscar investigar se uma autorização implícita estaria presente. Para isso, teremos de nos deter em critérios de razoabilidade, já que, como vimos, não há consenso entre os juristas sobre como se poderia reconhecer tal espécie de autorização.

Desde já é válido ressaltar a fragilidade de que sempre se reveste o critério de razoabilidade. Entretanto, como é a proposta deste estudo realizar função de certa forma similar à de um juiz, não se poderia escusar de dizer o direito.

\section{A crise no Iraque}

Saddam Hussein chegou ao poder na República do Iraque no ano de 1979, após afastar violentamente outros membros do governo. Sua base de sustentação era o partido Baath, sunita, que controlava de maneira ditatorial a população iraquiana, composta por uma maioria xiita, uma elite sunita (elite intelectual e, então, também política), e um contingente de curdos que vivem sobretudo no Norte do país.

As relações que o regime baathista possuía com o governo americano durante a década de 80 eram de aliança contra o regime dos aiatolás do Irã. Os EUA tiveram um papel relevante na guerra Irã-Iraque, terminada sem vencedor, fornecendo armas e inteligência - embora também tenham fornecido, de maneira clandestina, armas para o regime dos aiatolás. Após a guerra entre os países árabes, Saddam Hussein invadiu, em 2 de agosto de 1990, o vizinho Kuwait, estado soberano, o que deu início ao longo período de animosidades entre os EUA e o Iraque. 
A invasão do Kuwait pelo Iraque foi tratada no Conselho de Segurança, forjando-se a resolução 678 , que autoriza aos países engajados com o Kuwait a utilizar-se de "todos os meios necessários" para implementar a resolução 660 e todas as resoluções subseqüentes que fossem "relevantes". A resolução 660 é justamente a que condena a invasão do Kuwait e exige a retirada das tropas iraquianas. Após o envio de tropas da ONU e o bombardeio de Bagdá, o exército iraquiano retira-se do Kuwait e o Conselho de Segurança adota a resolução 687, que impõe diversos encargos ao Iraque. Entre eles, o estabelecimento de uma zona desmilitarizada entre o Kuwait e o Iraque e a extinção de todas armas de destruição em massa, como armas químicas e mísseis balísticos do território iraquiano.

Desde a feitura da resolução 687, o Iraque nunca mais buscou invadir o Kuwait. Em relação à destruição das armas de destruição em massa, entretanto, as questões foram mais delicadas. Após um período bem-sucedido em que inspetores internacionais de fato encontraram e destruíram armas no Iraque, Saddam Hussein expulsou, em 1997, todos os inspetores americanos que estavam em seu território. Em solidariedade aos colegas, o conjunto dos inspetores retirou-se do território, causando uma grave crise em 1998.

Já na época da crise o governo americano defendia ser desnecessária nova resolução do Conselho de Segurança, alegando que a resolução 678 seria bastante. Entretanto, apesar de terem havido diversos bombardeios à época, não houve guerra generalizada. Após os ataques de 11 de setembro em Nova Iorque e da guerra do Afeganistão, o presidente Bush começou a falar claramente em guerra generalizada com o Iraque, baseando-se primeiramente em supostas ligações entre a rede terrorista Al-Qaeda e o regime de Saddam Hussein. Essa linha argumentativa, entretanto, foi abandonada face à falta de provas. A grande defesa da guerra passou a ser, então, as armas de destruição em massa que o Iraque possuiria e de cuja posse os EUA estariam apresentando prova.

Foi adotada de maneira unânime a resolução 1441 do Conselho de Segurança, e, após quatro anos, inspetores voltaram ao Iraque. A resolução alertava para "graves conseqüência" para o Iraque se este descumprisse as medidas previstas. Os EUA engajam-se numa ampla campanha a fim de obter uma resolução do Conselho de Segurança específica para uma nova guerra com o Iraque que autorizasse a deposição do regime de Saddam Hussein. O inspetor-chefe Hans Blix diz em 14 de fevereiro de 2003 que havia ocorrido "progresso moderado". Em 24 de fevereiro EUA, Grã-Bretanha e Espanha propõem ao Conselho uma resolução que 
autorize definitivamente a invasão. França, Alemanha e Rússia, por sua parte, propõem que esforços sejam feitos no sentido de conseguir-se uma solução pacífica. Após ter ficado claro para os EUA e Grã-Bretanha que, além deles, os únicos membros do Conselho de Segurança que votariam pelo Resolução que autorizaria a guerra eram Espanha e Bulgária, além do prometido veto de China, França e Rússia, a votação não ocorre. Em 19 de março a guerra tem início.

\section{A tese de Goldsmith}

Em 17 de março de 2003, dois dias antes do início da Guerra do Iraque, o attorney-general Lord Goldsmith respondeu ao questionamento do Congresso britânico sobre a legalidade de uma possível guerra contra o Iraque. A opinião de Goldsmith enviada ao parlamento foi de que a guerra era, sim, legal, por autorização do Conselho de Segurança ${ }^{36}$.

É válida a transcrição da tese de Goldsmith:

"A autorização existe pela força combinada das resoluções 678, 687 e 1441. A resolução 678 autoriza a força para expulsar as forças iraquianas do Kuwait e para restaurar a paz e a segurança na área. A resolução 687 impôs obrigações duradouras sobre o Iraque, no sentido de eliminar suas armas de destruição em massa de forma a restaurar a paz e a segurança internacionais na área. A resolução 687 suspende mas não extingue a autoridade de uso da força concedida pela resolução 678; tal autoridade pode ser reavivada no caso de uma quebra material por parte do Iraque da resolução 687."

\footnotetext{
${ }^{36}$ Hoje se sabe que o attorney-general britânico, a despeito da opinião que enviou ao Congresso, confiou ao primeiro-ministro britânico Tony Blair suas dúvidas quanto à legalidade da guerra sem uma nova resolução que a autorizasse expressamente. Fonte: BBCNews, disponível em http://www.bbc.co.uk/1/hi/uk_politics/vote_2005/frontpage/4492439.stm.
} 
"Na resolução 1441, o Conselho de Segurança determinou que o Iraque está em estado de quebra material da resolução 687, mas deu uma 'oportunidade final' ao Iraque de 'cumprir com suas obrigações de desarmamento', e advertiu o Iraque de 'graves conseqüências' se ele não o fizesse. Decidiu ainda na resolução 1441 que, se o Iraque falhasse em cooperar e cumprir a implementação, incorreria em outra quebra material da resolução 687."

${ }^{66}$ Está claro que o Iraque falhou em cumprir as obrigações e está [em março de 2003] em estado de quebra material da resolução $687^{37}$."

\section{Houve autorização?}

Em 1990, quase treze anos antes da Guerra do Iraque, o Conselho de Segurança autorizou, na sua Resolução 678, o uso de "todos os meios necessários" para que se atingisse aquilo que foi exigido na resolução 660, e nas subseqüentes resoluções "relevantes". A Resolução 678 é vaga; não afirma, por exemplo,

se as "relevantes" resoluções subseqüentes deveriam necessariamente estar relacionadas com a invasão do Kuwait, ou se seriam quaisquer outras resoluções do Conselho que fossem dirigidas ao Iraque. Tampouco foi estabelecido um termo ou prazo para a autorização.

Se considerarmos que a resolução estava vigente, como afirmam Steven, Wall e Dinlenc, a situação de "veto reverso" descrita por Lobel e Ratner estaria plenamente configurada. Ao determinar-se que somente uma revogação expressa do Conselho de Segurança, ou um tratado de paz formal, extinguem a autorização, estaria-se concedendo o direito a quaisquer dos cinco membros permanentes do Conselho (que poderiam vetar uma revogação) que aterrorizassem indefinidamente algum país que uma vez esteve sujeito às forças da ONU. Considerando-se todo o feitio da Carta, que busca tornar a guerra uma situação excepcional, tal hipótese simplesmente não pode ser aceita. Outra razão para que não

\footnotetext{
${ }^{37}$ BBCNews, disponível em http://newsvote.bbc.co.uk/mpapps/pagetools/print/news.bbc.co.uk/2/hi/uk_news/politics/vote_2005/frontpage /4492195.stm
} 
possa ser aceita a idéia de que a autorização estava plenamente vigente é que a resolução 1441 fala em "oportunidade final" para o Iraque cumprir com suas obrigações. Ora, se o Conselho falou que pretende dar uma última chance ao Iraque, é claro que entendeu que o uso da força não estava autorizado no momento da redação da resolução 1441. Com efeito, seria absurdo imaginar que no dia de expedição da resolução que concede tal oportunidade final ao Iraque os Estados Unidos invadissem o país árabe em nome do Conselho.

$O$ attorney-general não vai tão longe quanto Steven, Wall e Dinlenc, pois fala em efeitos suspensos da resolução 678, que podem ser reavivados frente a uma quebra material. Ainda assim, o argumento não se sustenta. Ora, se quem suspendeu os efeitos, como admite o próprio Goldsmith, foi o Conselho de Segurança na resolução 687, somente a ele poderia competir determinar como e quando reavivar os efeitos da resolução 678. Se o Conselho fez questão de afirmar que o Iraque estava em estado de quebra material das resoluções anteriores, somente ao

Conselho caberia determinar a situação do Iraque quanto a suas obrigações no período posterior à resolução 1441.

Se comparada com a situação de Kosovo, que na visão de D'Amato era revestida de uma "quase-legalidade", a Guerra do Iraque também parece ficar aquém. Em Kosovo, havia uma crise humanitária acontecendo naquele momento, de proporções terríveis. No Iraque, acreditava-se que, talvez, armas de destruição em massa estivessem sendo fabricadas embora os EUA e a Grã-Bretanha afirmassem ter certeza, ficou provado posteriormente que era uma certeza leviana, pois de fato as armas não existiam. É fato que Saddam Hussein também promoveu massacres em sua população, mas estes não estavam ocorrendo de maneira tão dramática quanto no passado do Iraque, ou quando da crise de Kosovo, de forma que pudessem justificar uma ponderação das regras contidas na Carta. Em Kosovo, havia maioria de votos no Conselho de Segurança a favor de intervenção. No Iraque, o número de votantes teria que mais que dobrar para chegar aos 9 votos exigidos. Em Kosovo, o 
único veto era da Rússia, que possuía relações com a Iugoslávia que ela não queria trair. No Iraque, três dos cinco membros permanentes dispuseram-se a vetar a resolução.

A tese de que o "calor da guerra" não permite que para cada passo se exija nova resolução também é insustentável. Isto porque a Guerra do Iraque não foi um "passo" da Guerra do Golfo. Os EUA deram-se ao trabalho de realizar uma campanha de grande proporção e de longa duração para conseguir uma nova resolução. Somente quando ficou claro que não se conseguiria tal resolução eles reafirmaram a vigência da Resolução 678. Ora, quem está no "calor da guerra", $e$ compreende a si mesmo como devidamente autorizado, de forma alguma paralisará suas atividades buscando uma nova resolução, que somente enfatize o que já foi autorizado. Assim, percebemos não ter havido autorização do Conselho de Segurança para a Guerra do Iraque. 


\section{Quarto Capítulo - um costume instantâneo?}

Até o momento, estivemos ocupados de determinar a legalidade da Guerra do Iraque em relação ao Direito Internacional vigente no início da guerra. Valemo-nos dos

tratados aplicáveis ao direito à guerra, e de costumes consagrados e provados no Direito Internacional (ainda que

possivelmente não mais vigentes). Será, entretanto, que a Guerra do Iraque pode ter modificado o Direito Internacional, de maneira que ele a legitime por meio de um costume novo, ainda por ser provado?

Vimos que a ordem internacional não conhece hierarquia entre as fontes tratado e costume (REZEK, 2002). Assim, quando em conflito um costume e um tratado, aplica-se a regra especial, e, na falta desta, a mais recente. Portanto, se um novo costume surgisse com a nova guerra, ou a partir dos ataques de

11 de setembro, ele seria capaz de se tornar uma terceira exceção, ou uma ampliação do direito à legítima defesa. Desta maneira, não apenas o direito à legítima defesa preemptiva que exige a iminência de um ataque - existiria, mas também o direito à legítima defesa preventiva, aquele que, como vimos, surge do mero armamento excessivo de um possível inimigo.

Para melhor compreender como isso poderia se dar, devemos estudar um pouco da teoria do costume em direito internacional.

Em seu art. 38, b) o Estatuto da CIJ define o costume internacional como "prova de uma prática geral aceita como sendo o direito". Deixando de lado a pertinente crítica de Mello $^{38}$ de que o costume não é a prova da prática, mas a própria prática, a definição fornece os dois elementos que a doutrina costuma apontar no costume internacional: o material ou objetivo (a "prática geral") e o subjetivo ou opinio juris ("aceita como sendo o direito")"

\footnotetext{
38 op. cit., pg. 280.

${ }^{39}$ Rezek, $113 \mathrm{p}$.
} 
Costumes consagrados, tal como o pacta sunt servanda, não oferecem problema ao aplicador do direito. Não se pode dizer o mesmo, todavia, de costumes novos. Como se forma a prática?

A formação de um costume é algo reconhecidamente difícil, como nota Roberts:

"The process of custom formation is inherently uncertain, with no clear guide to the amount, duration, frequency, and continuity of state practice required to form a custom. The unwritten nature of traditional custom makes its content inherently insecure, while requiring repeated practice is 'too clumsy and slow' to accommodate the fast-paced evolution of law. Traditional custom is to be based on general and consistent state practice, but selective analysis inheres in this approach because of the impossibility of thoroughly analyzing the practice of almost two hundred states. This selectivity results in a 'democratic deficit' because most customs are found to exist on the basis of practice by fewer than a dozen states." 40

Assim, todo aplicador do direito encontra-se diante de um dilema quando confrontado com a tentativa de prova de um possível novo costume. Se exigir que a prática seja excessivamente prolongada, generalizada e contínua, é capaz de negligenciar costumes legítimos nunca possam ser provados. Se é pouco exigente em relação à prova da prática, porém, pode impor à comunidade internacional como um todo determinadas práticas comuns apenas a um número reduzido de Estados, estados estes que muitas vezes compartilham o mesmo interesse.

A Corte Internacional de Justiça já se pronunciou no sentido de que não há um prazo estabelecido para que se possa dizer que há uma prática ${ }^{41}$, e grande parte dos autores concorda com essa visão (REZEK, 2002, MELLO, 2001). Assim, fica

descartado um requisito temporal. Mas e quanto a uma continuidade, uniformidade e generalidade? Mais especificamente, quantas repetições seriam necessárias para que se formasse uma prática? Quantos estados deveriam aceitá-la?

Sejamos específicos. Para que se possa dizer que a guerra do Iraque é legal segundo o novo direito costumeiro, é

\footnotetext{
${ }^{40}$ ROBERTS, Anthea Elizabeth. "Traditional and Modern Approaches to Customary International Law: a Reconciliation". American Journal of International Law. Vol. 95:757, pg. 767.

${ }^{41}$ Apud Rezek, op. cit.
} 
necessário que esse direito costumeiro possa ser provado, como ensina Rezek ${ }^{42}$ : "A parte que alega em seu prol certa regra costumeira deve provar sua existência e sua oponibilidade à parte adversa: disse-o a Corte Internacional de Justiça no julgamento do caso Direito de asilo". Como autores identificam o surgimento do novo costume de ataque preventivo na Guerra do Iraque, ou mais cedo dois anos apenas, nos ataques de 11 de setembro

O que forma a prática, porém, é matéria bastante mais controversa. Rezek $^{43}$ fala em procedimento regularmente repetido. Que não existe um prazo mínimo para que o costume surja é apontado por diversos autores, já tendo a Corte Internacional de Justiça decidido nesse sentido. Pode, porém, o costume formar-se sem a repetição, ou seja, surgir com apenas uma prática?

A nosso ver, se tal hipótese for admitida, como o faz Strupp $^{44}$, será o mesmo que dispensar o elemento material do costume, à maneira de Bin Cheng ${ }^{45}$. Se um determinado ato foi

praticado somente uma vez, ou poucas vezes, não se pode propriamente dizer que há prática ou uso. Dessa maneira, o único elemento do costume passaria a ser a opinio juris.

\section{"Instant custom"}

É de fato exatamente isto, o surgimento de costume sem prática, ou diante de prática inconclusiva, o que defendem os teóricos do "instant custom", o costume instantâneo.

A opinio juris é geralmente conceituada como sendo a aceitação de que uma determinada prática é obrigatória segundo o direito internaciona ${ }^{46}$. Essa aceitação, entretanto, deve possuir alguma generalidade. Como demonstra Celso

\footnotetext{
${ }^{42}$ op. cit., pg. 117.

${ }^{43}$ op. cit., pg. 114.

${ }_{44}^{44}$ apud Mello, op cit, pg. 278.

${ }^{45}$ Ibibid.

${ }^{46}$ Ibid.
} 
Mello, há várias correntes em relação ao caráter de tal generalidade. Jimenez de Aréchaga diz que é mais importante o

"consenso geral" do que o consentimento individual de cada Estado $^{47}$. No mesmo sentido sintetiza Guzman:
"Ultimately, it is clear that the actual consent of an affected state is not itself required for that state to be bound by particular rule of CIL [Direito costumeiro internacional]" $\$ 8$

\begin{abstract}
Dessa maneira, não é necessário que haja consentimento iraquiano para que lhe possa ser oposta regra costumeira, de forma que o costume instantâneo pode ser obrigatório a quem o desrespeita, e naturalmente não dará seu consentimento.

Mas houve aceitação geral? Como vimos, é impossível acreditar que esta estava presente. O Conselho de Segurança se mostrou contrário, o secretário-geral das Nações Unidas declarou o conflito ilegal ${ }^{49}$. Ora, se o costume instantâneo dispensa o elemento objetivo, é válido pensar que deve ser mais exigente ainda quanto ao elemento subjetivo. Mas a opinio juris não é encontrada na questão.

É o caso de duvidar mesmo da aceitação dos próprios EUA da legítima defesa preventiva. Como é intrínseco a toda norma de direito internacional que seja válida para todos os Estados, é difícil imaginar que os EUA estejam dispostos a aceitar as implicações da vigência de uma norma como essa.
\end{abstract}

Se, a titulo de exemplo, a norma costumeira da legítima defesa preventiva tiver adquirido o seguinte caráter: "Nada impedirá o direito à legítima defesa preventiva diante de Estados que estejam ilegalmente adquirindo armas de destruição em massa, e possuam regime ditatorial", o Conselho de Segurança seria obrigado, perante o Direito Internacional, a nada fazer para impedir uma invasão indiana do Paquistão, pois é sabido que este último possui armas nucleares e é uma ditadura. Desta maneira, fica a dúvida se os EUA seriam capazes de elaborar uma regra de direito costumeiro instantâneo que justificasse a invasão do Iraque, e com a qual estivessem dispostos a conviver.

\footnotetext{
${ }^{47}$ Ibid.

${ }^{48}$ GUZMAN, Andrew T., Saving Customary International Law. UC Berkeley Public Law Research Paper No. 708721

${ }^{49}$ BBCNews, 16/09/2004. Disponível em http://news.bbc.co.uk/1/hi/world/middle_east/3661134.stm
} 
Buscamos no presente trabalho expor as principais visões sobre a legalidade de uma guerra qualquer - os critérios abstratos de legalidade - e também as visões sobre a legalidade da Guerra do Iraque em si. Ao longo desta monografia, inserimos conclusões quando elas nos pareceram sustentáveis o suficiente para serem aqui incluídas, ainda que contrariassem visões de determinados autores. Nossa tarefa, a partir de agora,

será buscar a síntese do que foi exposto acima, a fim de fornecermos nossa própria conclusão sobre a legalidade da guerra como um todo.

Vimos que a guerra nem sempre foi um ilícito internacional, mas é proibida pelo menos desde o advento da Carta da ONU, que o faz de maneira abrangente a todos os atos em seu art. 2(4). A Carta determina que o direito ao uso da força só nasce diante de duas hipóteses específicas, que constituem as únicas exceções à regra geral: a legítima defesa e a autorização do Conselho de Segurança.

A configuração do estado de legítima defesa e da autorização do Conselho de Segurança, entretanto, é controversa, como vimos. $O$ artigo 51 da Carta determina que o direito à legítima defesa somente surge diante de um ataque armado; mas a expressão "direito inerente" torna, para alguns,

a Carta ambígua, ou ainda, claramente favorável ao direito costumeiro anterior à Carta. Poderiam ser feitas diversas restrições quanto à teoria do direito inerente, como a de privilegiar um termo ambíguo sobre um termo claro, ou de confundir direito inerente com direito costumeiro. É certo

porém, que há autores que defendem justamente que a expressão direito inerente favorece o direito costumeiro pré-45, minando um possível consenso sobre o assunto.

O direito costumeiro antigo, ao contrário da Carta, não exige a ocorrência de ataque armado para que surja o direito à legítima defesa. Ficou assentado no caso Caroline que os requisitos para a legítima defesa preemptiva - à qual Bush 
aludiu em discurso - são a necessidade, a proporcionalidade e a iminência. Cada um deles é uma condição necessária para a configuração da legítima defesa antecipada, e esta só ocorre quando todos estão presentes. Tentamos demonstrar que os EUA não conseguiram preencher nenhum dos requisitos. $O$ uso da força era desnecessário segundo os critérios de Creig e desproporcional quanto à alegada ameaça, e a esta faltava iminência. Assim, mesmo que a legítima defesa preemptiva seja admitida no DI contemporâneo, a Guerra do Iraque não pode ser considerada legal do ponto de vista do art. 51 da Carta.

Resta a hipótese do art. 53, qual seja, a autorização do Conselho de Segurança. Vimos que sua configuração também não ocorre sempre de maneira cristalina. Há, neste campo, grande controvérsia, havendo desde aqueles que acreditam que as autorizações devem ser o mais restritas possível, como Lobel

e Ratner, até os que interpretam como autorização implícita toda falta de sanção do Conselho de Segurança a um ataque qualquer desferido por um Estado. Nosso critério foi a aplicação de alguma razoabilidade ao caso concreto, comparando-o com casos como Kosovo, e investigando o teor das próprias resoluções.

Vimos que a situação de Kosovo foi significativamente distinta da do Iraque, e que os critérios que foram aplicados para chamar aquela intervenção de "quase legal" não estiveram presentes na Guerra do Iraque. A tese de autorização plenamente vigente desde 1990 teve de ser rejeitada em razão dela confrontar-se com a "oportunidade final" dada pela resolução 1441 e por conter implicações inadmissíveis para o sistema internacional, qual seja o "veto reverso". Também foi

rejeitada a tese de Goldsmith, pois não poderia caber a membros isolados do Conselho determinar, contra a antecipada vontade do Conselho, a ocorrência de "quebra material" das determinações contidas nas resoluções do Conselho em relação ao Iraque, mormente a 687.

A última possibilidade de legalidade da guerra em questão adviria do surgimento de um "costume instantâneo", instituto 
controverso no Direito Internacional. Vimos, porém, que o elemento subjetivo do costume (o único exigido pela doutrina do costume instantâneo), não estava presente no caso, pois não se pode dizer que houve "aceitação geral" da guerra como sendo o direito.

Diante do exposto, concluímos que a Guerra do Iraque não conseguiu preencher satisfatoriamente os requisitos previstos por qualquer das duas exceções previstas pela Carta da ONU, devendo ser considerada, portanto, um ilícito internacional. 


\section{BIBLIOGRAFIA}

ACKERMAN, David. "International Law and the Preemptive Use of Force Against Iraq" CRS Report for Congress . Congressional Research Service The Library of Congress. Março, 2003.

\section{AREND, Anthony Clark. "International Law and the Preemptive Use of Military force". The Washington Quarterly. Primavera, 2003.}

CARON, David. Palestra proferida em 1 de abril de 2003 no Zellerbach Hall na Universidade de Berkeley, EUA.

CASSESSE, Antonio. Violence and Law in the Modern Age. Oxford, Polity Press, 1986.

CREIG, D.W. International Law. Londres, Butterworths, 1970.

KAUFMAN, Whitley R. P. "What's Wrong with Pre-emptive War?" The Joint Services Conference On Professional Ethics. 2005.

LOBEL, James \& RATNER, Michael. "Bypassing the Security Council" American Journal of Internationa.l Janeiro, 1999.

MELLO, Celso Duvivier de Albuquerque. Curso de Direito Internacional Público. Rio de Janeiro, Renovar, 2001

O'CONNELL, Mary Ellen. "The Myth of Preemptive Selfdefense" The American Society of International Law Task Force on Terrorism. Agosto, 2002.

REZEK, José Francisco. Direito Internacional Público (curso elementar).

São Paulo, Saraiva, 2002.

ROBERTS, Anthea Elizabeth. "Traditional and Modern Approaches to Customary International Law: a Reconciliation". American Journal of International Law. Vol. 95:757, pg. 767.

SCHWARZENBERGER, Georg. International Law and Order. Londres, Stevens and Sons, 1971

SHAW, MALCOLM NATHAN. International Law. Cambridge University Press, 1997. 
SIMMA, Bruno. "NATO, the UN and the Use of Force: Legal Aspects" European Journal of International Law. 10, 1999.

STEVENS, Paul Schott; WALL, Andru E. \& DINLENC, Ata. "The Just Demands of Peace and Security: International Law and the case against Iraq". The Federalist Society. Outubro, 2002. 